\title{
Contact with hospital syringes containing body fluids. Implications for medical waste management regulation
}

Patricia Volkow, MD, (1) Bénédicte Jacquemin, MD, (1) Diana Vilar-C ompte, MD, MSC, ${ }^{(1)}$ José Ramón C astillo, MD.(1)

Volkow P, Jacquemin B,Vilar-Compte D, Castillo JR. Contact with hospital syringes containing body fluids. Implications for medical waste management regulation.

Salud Publica Mex 2003:45:120-122.

The English version of this paper is available too at: http://www.insp.mx/salud/index.html

\begin{abstract}
A bstract
Objective. To determine amount of syringes used in the hospital and extent of contact with blood and body fluids of these syringes. Material and Methods. Syringe use was surveyed at a tertiary care center for one week; syringes were classified into the following four catego ries according to use: a) contained blood; b) contained other body fluids (urine, gastric secretion, cerebrospinal fluid, wound drainage); c) used exclusively for drug dilution and application in plastic intravenous (IV) tubes, and d) for intramuscular (IM), subcutaneo us (SC), or intradermic (ID) injections. Results. A total of 7157 plastic disposable syringes was used; 1227 $(17 \%)$ contained blood during use, $346(4.8 \%)$, other body fluids, 5257 (73\%) were used exclusively for drug dilution and application in plastic IV lines, and 327 (4.5\%) were utilized for IM, SC, or ID injections. An estimated 369140 syringes used annually, or eight syringes per patient per in-hospital day.All syringes were disposed of as regulated medical waste, in observance of the law. Conclusions. There is an urgent need to review recommendations for medical waste management by both international agencies and local governments, based on scientific data and a cost-benefit analysis, to prevent resource waste and further environmental damage. The English version of this paper is available too at: http://www.insp.mx/salud/index.html
\end{abstract}

Key words: medical waste; syringes; waste management; Mexico

\author{
Volkow P, Jacquemin B, Vilar-Compte D, Castillo JR. \\ Jeringas en contacto con sangre y fluidos corporales \\ utilizadas en el hospital. Implicaciones \\ para el manejo de desechos hospitalarios. \\ Salud Publica Mex 2003;45:120-122. \\ El texto completo en inglés de este artículo también \\ está disponible en: http://www.insp.mx/salud/index.html
}

\section{Resumen}

Objetivo. C uantificar el número de jeringas que se utilizan en el hospital y calcular cuántas de éstas entran en contacto con sangre o fluidos corporales. Material y métodos. Se hizo una encuesta del uso de jeringas en un hospital de tercer nivel de atención durante toda una semana. Se clasificaron, de acuerdo con el uso que se les dio, en cuatro catego rías: a) aspiración de sangre, b) otros fluidos corporales (orina, secreción gástrica, líquido cefalorraquídeo, drenaje de herida, etcétera), c) uso exclusivo para diluir medicamentos y administrarlos a través de tubos de terapia intravenosa, d) para aplicación de inyecciones intramusculares (IM), subcutáneas (SC) 0 intradérmicas (ID). Resultados. Se utilizó un total de 7157 jeringas plásticas desechables, 1227 (17\%) de las cuales contuvieron sangre durante su uso, 346 (4.8\%) otros líquidos corporales, 5257 (73\%) se usaron exclusivamente para diluir medicamentos y administrarlos mediante tubos de terapia intravenosa, y $327(4.5 \%)$ se usaron para inyecciones IM, SC O ID. El consumo anual de jeringas estimado fue de 369 140, o sea ocho jeringas por paciente por día de hospitalización. Todas las jeringas fueron desechadas como residuo peligroso biológico infeccioso (RPBI) de acuerdo con la N orma -087 Ecol 1995. Conclusiones. Existe una necesidad urgente de revisar las recomendaciones para el manejo de la basura médica regulada, tanto por agencias internacionales como por los gobiernos locales, que deberán basarse en información científica y en un análisis de costo beneficio para evitar el dispendio de recursos y un mayor daño al medio ambiente. El texto completo en inglés de este artículo también está disponible en: http://www.insp.mx/salud/index.html

Palabras clave: residuos de hospitales; jeringas; manejo de residuos; México

(1) Instituto $N$ acional de Cancerología. México, D.F., México.

Received on: September 26,2001 - Accepted on: 0 ctober 15, 2002

Address reprint requests to: PatriciaVolkow. Instituto N acional de Cancerología. Avenida San Fernando 22, colonia Tlalpan, 14000 México, D.F., México. E-mail: volkow@ infosel.net.mx 
E stablishing of special policies for handling hospital solid waste has become a burden for health budgets in many countries. International recommendations extended by World Health Organization (WHO) experts are based on colloquial data rather than on scientific evidence. ${ }^{1}$ Apparently, the aim of these recommendations is to prevent blood-borne diseases, although the potential risk of infection by accidental injury outside the hospital setting is minimal. ${ }^{2,3}$ In several countries these recommendations have resulted in initiatives to regulate hospital waste management. However, legislation increases the costs of hospital waste handling and results in unjustified spending of health budgets in developing countries. ${ }^{4,5}$ In addition, the environmental impact of these recommendations has not been assessed.

Few studies have described the characteristics of hospital waste and practically no studies have assessed to what extent hospital solid waste is contaminated with blood or other body fluids. The objective of this study was to assess the number of syringes that contained blood or body fluids, or those used exclusively for drugs dilution (DD) and application in plastic intravenous tubes (PIVT).

\section{Material and Methods}

A survey was conducted during week, from July 13 to July 19, 1998, at a tertiary level of care 143-bed oncology center. A questionnaire was applied daily to every nurse, physician, or paramedic on all shifts, in all wards where syringes were used and collected at the end of each shift. Syringes were classified and counted according to capacity, i.e., $1 \mathrm{ml}, 5 \mathrm{ml}, 10 \mathrm{ml}$, and 20 $\mathrm{ml}$. They were also classified according to use: A) taking blood samples, B) taking samples of other body fluids, C) used exclusively for DD and application in PIVL, and D) for intramuscular (IM), subcutaneous (SC), or intradermal (ID) injection.

\section{Results}

A total of 7157 syringes were used during the week surveyed as follows: 1227 (17.4\%) contained blood during use; $346(4.8 \%)$ contained other fluids (urine, gastric secretion, wound drainage); 5 257(73.4\%) were used exclusively for DD and application in PIVL, and $327(4.5 \%)$ were used for IM, SC, or ID injections (Table I). The use of syringes according to capacity was $6.86 \%$ for $1 \mathrm{ml}, 38.8 \%$ for $5 \mathrm{ml}, 36 \%$ for $10 \mathrm{ml}$, and $18.3 \%$ for $20 \mathrm{ml}$.

An annual use of 369140 syringes at the hospital was estimated, eight syringes per patient in-hospital day. The weight of empty syringes per year would

\begin{tabular}{|c|c|c|c|c|c|}
\hline \multicolumn{6}{|c|}{$\begin{array}{c}\text { Table I } \\
\text { Number AND PerCent OF SYRINGES by TYPE OF USE, } \\
\text { at ATERTIARY CARE CENTER. MeXICO, } 1998\end{array}$} \\
\hline Syringes & Blood & $\begin{array}{l}\text { Other body } \\
\text { fluids }\end{array}$ & $\begin{array}{l}\text { Drug dilution } \\
\% \text { plastic IV lines }\end{array}$ & $\begin{array}{l}\text { IM, SC, and } \\
\text { ID injections }\end{array}$ & Total \\
\hline N umber & 1227 & 346 & 5257 & 327 & 7157 \\
\hline 10 & $17.4 \%$ & $4.8 \%$ & $73.4 \%$ & $4.57 \%$ & 100 \\
\hline
\end{tabular}

IV: intravenous

ID: intradermic

IM: intramuscular

SC: subcutaneous

be $3733 \mathrm{~kg}$; $725 \mathrm{~kg}$ of which would never have contact with blood or any human tissue. The latter, plus the annual consumption of $1479 \mathrm{~kg}$ of 28104 plastic lines for infusion therapy, would add up to $4204 \mathrm{~kg}$ of waste with no infection potential at this hospital.

\section{Discussion}

From the beginning of the AIDS epidemic, the culture of disposable items has been fostered, to provide the public with the feeling of absolute safety, notwithstanding the fact that many items are currently sterilized in all surgery rooms in all countries with very high standards of safety. The culture of disposable item utilization has increased waste production, consumption of non-renewable resources, and damage to the environment. An adequate program of sterilization and knowledge of the type of waste produced at the hospital can help create a reasonable use of disposable items, and restore previous practices such as use of glass syringes for DD and application in PIVT. Preventing irreversible damage to the environment requires the development of a policy to reduce waste production, reuse material, and recycle hospital appliances. ${ }^{6}$

The average cost of medical waste handling in Mexico is $\$ 1.00$ US dollars (USD) per kilogram. Excessive costs of waste management in countries that over-regulate medical waste management-based more on political issues than on scientific data- is draining health budgets, which are particularly meager in developing countries. ${ }^{4,7}$ Hospital epidemiologists can contribute a great deal to saving money and protecting the environment by rationalizing medical waste management and the use of disposable items. ${ }^{8,9}$

Furthermore, it has been proposed that the introduction of plastic disposable syringes played a major role in altering the ecological balance of routes for blood-borne pathogens in low- and middle-income 
countries. ${ }^{10}$ Plastic disposable syringes meant for one use are reused without proper sterilization only in high-deprivation settings such as Africa and Latin America. Use of glass syringes, which may be adequate for proper resterilization, has been proposed as a way for preventing nosocomial HIV transmission and other blood-borne pathogens ${ }^{11}$ in middle- and low-income countries.

There is an urgent need to revise the recommendations for medical waste management by both international agencies and local governments, based on scientific data and a cost-benefit analysis. The use of disposable syringes in hospital settings should be rationalized; using properly sterilized glass syringes would save resources and prevent further environmental damage.

\section{References}

1. Coad A. Managing medical waste in developing countries. World Health 0 rganization, G inebra, 1992.W HO /PEP/RUD/94.1.W orld Health 0 rganization, 1994. /PEP/RUD/94.1.
2. Resnick L, Veren K, Salahuddin SZ, Tondreau S, Markham PD. Stability and inactivation of HTLV III/LAV under clinical and laboratory environments. JAMA 1986;255:1887-1891.

3. Henderson DK. Risk for occupational transmission of HIV-1 associated with clinical exposure. Ann Intern Med 1990;113:740-746.

4.Volkow P, Rangel-Frausto S, Ponce de León-Rosales S. Basura hospitalaria: comentarios sobre sus riesgos y su regulación. Enferm Infecc Microbiol Clin 1999;19:1-4.

5. RutalaW C, Mayhall G.The Society for Hospital Epidemiology of America; medical waste. Infect Control Hosp Epidemiol 1991;12:38-48.

6. McVeigh P. OR nursing and environmental ethics. Medical waste reduction, reuse and recycling.Today's O R N urse 1993;15:13-18.

7. Rutala W A, Weber DJ. Infectious waste. N Engl J Med 1991;325: 578-582.

8. Daschner F.The hospital and pollution: Role of the hospital epidemiologist in protecting the environment. En:W enzel $R$, ed. Prevention and control of nosocomial infection. 3rd ed. Baltimore, (MD) W illiam \& W ilkins; 1997:595-605

9. Decker MD, Schaffer W. The relationship between the hospital and the community. En: Bennett JV, Brachman JV, ed. Hospital infection. $4^{\text {th }}$ ed. Philadelphia (PA): Lippincott-Raven Press, 1998;181-188.

10. D rucker E,Alcabes PG, Marx PA.The injection century: Massive unsterile injections and the emergence of human pathogens. Lancet 2001;358:1989-1992.

11. Petithory JC, De Loye J, Guesnu M, Parienne P, Milgram M, Tardy M et al. Prevention de la transmission par les seringues et aiguilles de $\mathrm{VIH}$ en France et en Afrique. Bull Acad N atl Med 1989;173:415-420. 